\title{
Evaluation of Reading Habits of Teacher Candidates: Study of Scale Development
}

\author{
Senem Seda Şahenk Erkan ${ }^{1}$, Asude Balaban Dağal ${ }^{2}$, Özlem Tezcan ${ }^{3}$ \\ ${ }^{1}$ College of Foreign Languages, Marmara University, Turkey \\ ${ }^{2}$ Education Faculty, Marmara University, Turkey \\ ${ }^{3}$ Education Faculty, Kocaeli University, Turkey \\ Correspondence: Senem Seda Şahenk Erkan, College of Foreign Languages, Marmara University, Göztepe, İstanbul, \\ Turkey, Tel: 90-533-251-97-41.
}

Received: September 2, 2015

Accepted: September 17, 2015

Online Published: October 9, 2015

doi:10.11114/jets.v4i1.1068

URL: http://dx.doi.org/10.11114/jets.v4i1.1068

\begin{abstract}
The main purpose of this study was to develop a valid and reliable scale for printed and digital competencies ("The Printed and Digital Reading Habits Scale"). The problem statement of this research can be expressed as: "The Printed and Digital Reading Habits Scale: is a valid and reliable scale?" In this study, the scale development method was employed, and two instruments were used: "The Personal Information Form" (sex, age, university, department, and grade)" and 5 Likert-Type "Printed and Digital Reading Habits Scale". Five hundred twenty-four teacher candidates $\left(1^{\text {st }}\right.$ and $4^{\text {th }}$ grades) from the departments of Turkish Teaching, Elementary School Teaching, and Pre-School Teaching at Marmara University and Kocaeli University participated in this study. Based on the results of the validity and reliability analyses obtained in the present study, the number of items in the scale was reduced to 18. The KMO value of the scale was found to be .904 . The coefficient of Cronbach's Alpha of the scale was found to be .82 . Based on the factor analysis of the scale, it was discovered that it had three sub-factors. The test-retest results indicated that the scale would not change at any time (t: $-1.664, \mathrm{p}<0.05)$. In conclusion, it is possible to describe "The Printed and Digital Reading Habits Scale" is a valid and reliable scale.
\end{abstract}

Keywords: printed reading, digital reading, scale development method, teacher candidates

\section{Introduction}

\subsection{Problem}

Nowadays, with the technological developments, the world aims to acquire habits and evaluating such information for everybody (Önal, 2010). The economic and social variations make large consequences for the education systems in 21 st century. Nowadays, the society becomes more and more complex. In the complex society the individuals need more metacognitive skills and competencies for social interaction and economical participation. To gain these competencies, first of all, the students should have to learn how to learn and should have to learn analyzing and criticizing their learnings. Nowadays, traditional education is moving toward to constructivist education. In constructivist education, students get the responsibility of their learnings (Tanriverdi, Ulusoy and Turan, 2012). And this make them more conscious in their learning and in this approach, students attempt to learn everything more than traditional (Geçer, 2012). Consequently, if the individuals read so much, actually they can get these competencies easily.

The factors, supporting education and ensuring social and personal development of individuals are listed below $\left(21^{\text {st }}\right.$ Century Skills, Education \& Competitiveness, 2008):

- Critical thinking,

- $\quad$ Quite high problem-solving skill,

- Creativity,

- Strong collaborative and communication skills,

- Making efficient use of information, tools, an opportunities, 
- Improvement of economic and health facilities.

An attempt is made to introduce basic literacy skills to individuals through the education reforms and policies. In Turkey, many institutions and organizations (specially the Ministry of National Education) organize activities with the reading habits. For example, the Ministry of National Education, provincial directorates of national education and municipalities undertake many organizations such as "Now It Is Time for Reading Project", "Reading Time and Reading/Comprehension Speed Map Project", etc... In addition, schools conduct some reading projects. However, the majority of university students do not have any regular and critical reading culture (Odabaş, Odabaş \& Polat, 2008).

Reading is one of the most important indicators of development in societies. It can be said that achieving development through realizing the change at personal and social levels depends on the level and quality of relationship (Y1lmaz, Köse, Korkut, 2009). Reading is an activity that can be conducted for learning, increasing one's general knowledge, improving creativity, progressing in career and increasing success (İyibilgin, 2004).

Reading habit is defined as "making reading a need and considering it part of life" (Bircan and Tekin, 1989). The person perceives reading as a need. Reading activity continues for all life (Gönen, Çelebi-Öncü, Iş1tan, 2004; Saracaloğlu, Bozkurt, Serin, 2003; Y1lmaz, 1992). It is not likely that students who do not have any reading habit and who fail to comprehend what they read will succeed in their lessons, improve their vocabulary and gain new experiences (Ünalan, 2006).

Additionally, the individuals acquire most of their knowledge through reading. Today, reading involves printed and digital (computer and the Internet). Printed reading refers to reading various printed materials such as books, magazines, newspapers and encyclopedias. But, digital reading, which started in the late of $20^{\text {th }}$ century, composes with the computers, tablets, smart phones, etc... The advantages of digital reading are enumerated below (Belisle, 2004):

1. It allows accessing many texts about a specific topic rapidly,

2. It enables one to read and examine a great variety of texts at the same time.

The biggest disadvantage of digital reading is physical fatigue. It causes harm in eyes particularly (Vandendorpe, 1999). Despite all, the number of e-books (Google Book Search, Google Livres, Yahoo [Open Content Alliance (OAC)], Bibliothèque numérique européenne [BNUE], UNESCO [World Digital Library], Gallica) reached almost 10.000 .000 in 2010 (Tessier, 2010).

Kırmızı (2012), Bozpolat (2010), Arslantürk and Saracaloğlu (2010), Demir (2009), Odabaş, Odabaş and Polat (2008), Gömleksiz (2004) and Nell (1988) focused on printed reading, but did not give any coverage to digital reading at all. In consideration of the foregoing, the problem statement of the study was determined as: "Is the scale form developed in regard to teacher candidates 'printed and digital reading habits valid and reliable?"

This research aimed to create a valid and reliable scale form for measuring teacher candidates' printed and digital reading habits.

\section{Method}

The scale development method was employed in this study. In general, it determines construct validity through factor analysis as a statistical method (Gorusch, 1983). The "Exploratory Factor Analysis" was made in the study. The scale was divided into sub-factors and its construct validity was determined by ascertaining the factor loadings of all items in the scale through factor analysis.

"Factor analysis" is the technique used for determining the number of independent variables that contribute by explaining a variable depending on more than one variable as well as the factor loadings of such independent variables. One of the most important objectives of this analysis is to search the origin of dependency among variables. Based on such relationships, data are presented more meaningfully and in summary (Turgut and Baykul, 1992; Balc1, 1995, Cited by Semerci, 2003). Factor analysis is a multivariate analysis technique frequently used in many fields, such as social sciences (Tatlidil, 1992, Cited by Semerci, 2003).

In addition, Cronbach's Alpha reliability analyses were performed on the entire form and its sub-groups in order to test the reliability of the scale. Test-retest reliability analyses were carried out to measure the unchangeability of the scale in the course of time.

\subsection{Preparing the Scale Items}

Firstly, printed and digital reading habits required to be held by teacher candidates were searched in national and international literatures. A 40-item pool was created by using the questionnaire and scale forms used by Dökmen (1990), Gömleksiz (2004), Bozpolat (2010) and Kırmız1 (2012).

The developed item pool was converted into a questionnaire form. Then the opinions of 4 experts were received in 
regard to the questionnaire form. After that, all items rejected by the experts were removed from the questionnaire via Lawshe's technique, thereby creating a 25 -item form. The 25 -item form was administered to the pre-service teachers. The statistical analyses carried out indicated that the scale form consisted of 18 items and 3 sub-factors in total.

Sample

Five hundred twenty four teacher candidates $\left(1^{\text {st }}\right.$ and $4^{\text {th }}$ grades $)$ from the departments of Turkish Teaching, Elementary School Teaching and Pre-School Teaching at Marmara and Kocaeli University were participated in this study. The study group consisted of 524 teacher candidates. The percentages of the sample was shown below:

Table 1. Percentages of the Sample

\begin{tabular}{lll}
\hline & & $\%$ \\
\hline Sex & $\mathrm{M}$ & 76.9 \\
& $\mathrm{~F}$ & 23.1 \\
& $18-20$ & 45.6 \\
& $21-23$ & 46.6 \\
University & $24-26$ & 6.9 \\
& 27 and 27+ & 1 \\
Department & Marmara & 55.7 \\
& Kocaeli & 44.3 \\
\multirow{3}{*}{ Grade } & Elementary School & 33 \\
& Pre-School Education & 31.5 \\
& Turkish Education & 35.5 \\
& $1^{\text {st }}$ & 51.9 \\
\hline
\end{tabular}

\subsection{Data Collection Tools}

The Personal Information Form (5 items) and The Printed and Digital Reading Habits Scale (17 items) were used for data collection in the present study.

The Personal Information Form: The Personal Information Form was made up of 5 items (sex, age, university, department and grade).

The Printed and Digital Reading Habits Scale: This scale consisted of 17 items. It was a 5-point Likert-type scale. The choices in the scale were as follow "Strongly Agree (5)", "Agree (4)", "Slightly Agree (3)", "Disagree (2)", and "Strongly Disagree (1)". Accordingly, the teacher candidates were asked to select the most appropriate choice in regard to printed and digital reading skills.

The factors of this scale were divided into 3 sub-factors cited below:

-Factor 1: reading acquisitions: I am selective in reading. (10 items);

-Factor 2: printed reading: I read books. (4 items);

-Factor 3: digital reading: I read e-books. (3 items).

\section{Findings}

\subsection{Reliability}

The analyses showed that the scale had 4 factors. However, the reliability analysis of the $4^{\text {th }}$ factor yielded poor results, and the factor included only 2 items. Thus, the items included in the $4^{\text {th }}$ factor were excluded from analysis. Therefore, the analyses were made again from the very beginning.

Table 2. KMO Coefficient

\begin{tabular}{lll}
\hline KMO & & .904 \\
Bartlett's Test of Sphericity & Approximate Chi-Square & 3130.099 \\
& $\mathrm{sd}$ & 136 \\
& $\mathrm{p}$ & .000 \\
\hline
\end{tabular}

As seen in Table 2, the KMO value of "The Printed and Digital Reading Habits Scale" was .904. Since the KMO value was quite high, the factor loadings of the scale were able to be analyzed.

As the KMO coefficient comes close to 1, the data are considered fit for analysis. A KMO coefficient being equal to 1 refers to perfect fit. The KMO coefficient needs to be higher than 0.70 for the data to be fit for factor analysis (Büyüköztürk, 2007).

Barttlet's test yielded 3130.099. The result of Barttlet's test was found to be significant at the level of 0.001 . According to Barttlet's test, there was a correlation between the variables and factor analysis was to be made on such variables (Büyüköztürk, 2007). 
Table 3. Eigenvalue and Cumulative Percentage of the Factors

\begin{tabular}{lccc}
\hline Factor No & Eigenvalue & \multicolumn{3}{c}{ Cumulative Percentage } \\
\hline 1 & & 5.77 & 33.96 \\
2 & 1.92 & 45.25 \\
3 & & 1.35 & 53.22 \\
\hline
\end{tabular}

Table 3 demonstrates the eigenvalues of "The Printed and Digital Reading Habits Scale". According to the analysis results, the scale items were divided into 3 sub-dimensions, and the sum of such 3 sub-dimensions explained $53.22 \%$ of the printed and digital reading habits of the teacher candidates.

Table 4. Arithmetic Average and Standard Deviation of the Items

\begin{tabular}{llllllll}
\hline Items & $\mathrm{N}$ & Mean & sd & Items & $\mathrm{N}$ & Mean & sd \\
\hline $\mathrm{s} 1$ & 524 & 4.05 & .965 & $\mathrm{~s} 16$ & 524 & 4.42 & .789 \\
$\mathrm{~s} 4$ & 524 & 3.42 & 1.176 & $\mathrm{~s} 17$ & 524 & 4.55 & .713 \\
$\mathrm{~s} 5$ & 524 & 3.15 & 1.147 & $\mathrm{~s} 18$ & 524 & 4.42 & .789 \\
$\mathrm{~s} 6$ & 524 & 2.52 & 1.081 & $\mathrm{~s} 19$ & 524 & 4.50 & .662 \\
$\mathrm{~s} 7$ & 524 & 2.40 & 1.213 & $\mathrm{~s} 20$ & 524 & 4.39 & .748 \\
$\mathrm{~s} 13$ & 524 & 2.82 & 1.127 & $\mathrm{~s} 21$ & 524 & 4.29 & .798 \\
$\mathrm{~s} 14$ & 524 & 2.47 & 1.170 & $\mathrm{~s} 22$ & 524 & 4.45 & .770 \\
s15 & 524 & 4.36 & 0.895 & $\mathrm{~s} 23$ & 524 & 4.08 & .973 \\
& & & & $\mathrm{~s} 24$ & 524 & 4.12 & .836 \\
\hline
\end{tabular}

As seen in Table 4, the averages of the 18-item scale varied between 2.40 (minimum) and 4.55 (maximum). Moreover, the standard deviation values of the scale varied between .662 (minimum) and 1.213 (maximum).

Table 5 presents the factor analysis results concerning "The Printed and Digital Reading Habits Scale". According to the factor analysis, the distribution of the scale items divided into 3 dimensions by dimensions is as follows; 1st dimension: 10 items; 2nd dimension: 4 items and 3rd dimension: 3 items.

The item analysis results employed when determining the validity of the scale are provided below.

Table 5. Factor Analysis

\begin{tabular}{|c|c|c|c|}
\hline Items & Factors & \multicolumn{2}{|c|}{ Factor Loadings } \\
\hline s15 & 1 & .75 & \\
\hline s16 & 1 & .75 & \\
\hline s17 & 1 & .73 & \\
\hline s18 & 1 & .71 & \\
\hline s19 & 1 & .63 & \\
\hline s20 & 1 & .52 & \\
\hline s21 & 1 & .51 & \\
\hline s22 & 1 & .75 & \\
\hline s23 & 1 & .75 & \\
\hline s24 & 1 & .73 & .53 \\
\hline s1 & 2 & & .66 \\
\hline s4 & 2 & & .70 \\
\hline s5 & 2 & & .78 \\
\hline s6 & 2 & & .53 \\
\hline s7 & 3 & & .7 \\
\hline s13 & 3 & & .7 \\
\hline s14 & 3 & & .6 \\
\hline
\end{tabular}

\subsection{Validity Analyses Regarding Item Distinctiveness}

.65

The distinctiveness of the items included in each factor was investigated. According to the results of item analyses, it was found to be significant at 0.05 significance level $(\mathrm{p}<0.05)$ in all items of the dimensions F1 "Reading Acquisitions", F2 "Printed Reading", and F3 "Digital Reading". These findings were interpreted as follows: The items in the scale had a high reliability and could make a distinction between the graders of the scale in terms of the characteristics intended to be measured.

Table 6: Independent Groups T-Test Results for the Entire "Printed and Digital Reading Habits Scale"

\begin{tabular}{llllllllll}
\hline & \multicolumn{3}{c}{ Upper Quarter } & \multicolumn{3}{c}{ Lower Quarter } & \multicolumn{4}{c}{ Comparison } \\
\hline & $\mu$ & $\mathrm{sd}$ & $\mathrm{n}$ & $\mu$ & $\mathrm{sd}$ & $\mathrm{N}$ & $\mathrm{sd}$ & $\mathrm{t}$ & $\mathrm{p}$ \\
\hline F1 & 4.95 & 0.71 & 141 & 3.63 & 0.45 & 141 & 280 & 33,86 & 0.000 \\
$\mathrm{~F} 2$ & 4.17 & 0.40 & 141 & 2.32 & 0.48 & 141 & 280 & 34,54 & 0.000 \\
$\mathrm{~F} 3$ & 3.62 & 0.44 & 141 & 1.63 & 0.33 & 141 & 280 & 43,09 & 0.000 \\
\hline
\end{tabular}

The table 6 presents distinctiveness results concerning 3 factors of "The Printed and Digital Reading Habits Scale". It was found that all factors of the scale displayed significant relationships at the significance level of 0.001 in terms of distinctiveness levels. 


\subsection{Findings Concerning Reliability}

Tables 7-11 present item analysis results for all sub-dimensions of "The Printed and Digital Reading Habits Scale".

Table 7. Relationships between the Dimensions of "The Printed and Digital Reading Habits Scale"

\section{Cronbach's Alpha Coefficient: 0.82}

\begin{tabular}{llllllll}
\hline & Total & & & $\mathrm{F} 1$ & \multicolumn{3}{c}{$\mathrm{F} 2$} \\
\hline & $\mathrm{r}$ & $\mathrm{p}$ & $\mathrm{r}$ & $\mathrm{p}$ & $\mathrm{r}$ & $\mathrm{p}$ \\
\hline Reading Acquisitions & & 0.85 & $\mathrm{p}<0.01$ & & & & \\
Printed Reading & 0.69 & $\mathrm{p}<0.01$ & 0.42 & $\mathrm{p}<0.01$ & & \\
Digital Reading & 0.51 & $\mathrm{p}<0.01$ & 0.12 & $\mathrm{p}<0.01$ & 0.52 & $\mathrm{p}<0.01$ \\
\hline
\end{tabular}

Table 7 shows reliability results regarding "The Printed and Digital Reading Habits Scale" as well as the results of item analyses covering factor dimensions. According to the analysis results, the Cronbach's Alpha coefficient of the scale was 0.82 , which was a high value. The item-total analysis results demonstrated that the correlation values of all dimensions were significant at the level of 0.01 .

Table 8 present the Cronbach's Alpha levels of all dimensions as well as relevant item analysis results.

Table 8. The Cronbach's Alpha Coefficient of the Dimension "Reading Acquisitions (F1)" of "The Printed and Digital Reading Habits Scale"

\begin{tabular}{lll}
\hline F1 & & \\
Reading Acquisitions & Item-Total Correlation & Cronbach's Alpha Coefficient Item Remaining \\
\hline s18 & .738 & .873 \\
s19 & .731 & .876 \\
s22 & .727 & .874 \\
s17 & .677 & .878 \\
s16 & .642 & .880 \\
s20 & .684 & .877 \\
s15 & .600 & .883 \\
\hline F1 & & \\
Reading & Acquisitions Item-Total Correlation Cronbach's Alpha Coefficient Item Remaining \\
\hline s21 & .565 & .885 \\
s24 & .554 & .886 \\
s23 & .490 & .894 \\
\hline
\end{tabular}

F1 Cronbach's Alpha Coefficient: 0.89

As seen in the Table 7, the Cronbach's Alpha of the dimension "Reading Acquisitions" of "The Printed and Digital Reading Habits Scale" was found to be 0.89 . Item remaining was not considered necessary as the removal of any item from the dimension "Reading Acquisitions" would not increase the Cronbach's Alpha value more.

Table 9. The Cronbach's Alpha Values of the Dimension "Printed Reading (F2) of "The Printed and Digital Reading Habits Scale"

\begin{tabular}{lcc}
\hline F2 & Printed Reading Item-Total Correlation Cronbach's Alpha Coefficient Item Remaining \\
\hline s6 & .429 & .594 \\
s5 & .547 & .507 \\
s4 & .430 & .596 \\
s1 & .349 & .643 \\
\hline
\end{tabular}

\section{F2 Cronbach's Alpha Coefficient: 0.66}

As seen inTable 9, the Cronbach's Alpha of the dimension "Printed Reading" of "The Printed and Digital Reading Habits Scale" was found to be 0.66 . Item remaining was not considered necessary as the removal of any item from the dimension "Printed Reading" would not increase the Cronbach's Alpha value more.

Table 10. The Cronbach's Alpha Values of the Dimension "Digital Reading (F3) of "The Printed and Digital Reading Habits Scale"

\begin{tabular}{lcc}
\hline F3 & \multicolumn{2}{l}{ Item-Total Correlation Cronbach's Alpha Coefficient Item Remaining } \\
Digital Reading & \\
\hline s7 & .30 & .48 \\
s13 & .30 & .48 \\
s14 & .41 & .30 \\
\hline
\end{tabular}




\section{F3 Cronbach Alpha Coefficient:.53}

As seen in Table 10, the Cronbach's Alpha of the dimension "Digital Reading" of "The Printed and Digital Reading Habits Scale" was found to be 0.53. Item remaining was not considered necessary as the removal of any item from the dimension "Digital Reading" would not increase the Cronbach's Alpha coefficient more.

\subsection{Test-retest Reliability}

"The Printed and Digital Reading Habits Scale" was administered to 24-person group twice at the intervals of two weeks. In this way, the relationship between two applications was detected. Table 10 presents test-retest results.

Table 11. Group T-Test Results Concerning Test-Retest for "The Printed and Digital Reading Habits Scale"

\begin{tabular}{|c|c|c|c|c|c|}
\hline & Mean & $\mathrm{N}$ & $\mathrm{t}$ & $\mathrm{df}$ & $\mathrm{P}$ \\
\hline \multirow{2}{*}{ total-rfsstop } & 3.67 & 76 & -1.664 & \multirow{2}{*}{23.000} & \multirow{2}{*}{0.110} \\
\hline & 3.67 & 76 & & & \\
\hline \multirow{2}{*}{ f1toplam-rf1ss } & 2.986 & 76 & 0.000 & \multirow{2}{*}{23.000} & \multirow{2}{*}{1.000} \\
\hline & 2.986 & 76 & & & \\
\hline \multirow{2}{*}{ f2toplam-rf 2 ss } & 3.827 & 76 & -1.000 & \multirow{2}{*}{23.000} & \multirow{2}{*}{0.328} \\
\hline & 3.833 & 76 & & & \\
\hline \multirow{2}{*}{ f3toplam-rf3ss } & 2.984 & 76 & -1.735 & \multirow{2}{*}{23.000} & \multirow{2}{*}{0.096} \\
\hline & 2.997 & 76 & & & \\
\hline
\end{tabular}

As is seen in Table 11, no significant difference was determined at the significance level of 0.05 between the total scores obtained from the factors and the average scores obtained from the entire scale, according to the dependent-groups t-test results. That revealed that the scale was reliable in the sense of exchangeability in the course of time.

\section{Discussion and Conclusion}

In this study, a scale that could measure the printed and digital reading habits of faculty of education students from Marmara University and Kocaeli University and reveal their views and thoughts about printed and digital reading was developed. Based on the related literature as well as questionnaires and scales employed in previous studies, a 40-item pool was created. The 40 -item scale was presented to 4 experts to receive their opinions. Fifteen items were removed through Lawshe's technique. The 25 -item scale was administered to 524 students. Those items whose factor loadings were below .50 were excluded from analysis. The Varimax rotated principal components analysis was conducted.

According to the first analysis results, the KMO (Kaiser-Meyer-Olkin Measure of Sampling Adequacy) value was found to be .904, and Barttlet's test yielded 3130.099. Accordingly, the result of Barttlet's test was found to be significant at the level of 0.001 . According to Barttlet's test, there was a correlation between the variables, and factor analysis was to be made on such variables.

The factor analysis indicated that the scale consisted of 3 sub-factors and 17 questions. The Cronbach's Alpha reliability coefficients of 3 sub-dimensions of the scale were found to be $.89, .66$, and .53 respectively. The alpha reliability coefficient of the entire scale was found to be .82. These results showed that the scale was reliable both as a whole and in terms of sub-dimensions. Thus, it was a reliable scale. On the other hand, the fact that the Cronbach's Alpha reliability coefficient of the overall scale was higher than the coefficients of the sub-dimensions meant that the scale could be used both as a multidimensional scale and as a one-dimensional scale (Bozanoğlu, 2004). The scale contained items with a factor loading value higher than 0.45 .

In consideration of the foregoing, it is safe to say that it is a valid and reliable scale.

The related literature includes many similar studies. However, these studies are usually about printed reading habits while some are limited to questionnaire forms.

The items of scale forms used by Kırmızı (2012), Bozpolat (2010), Arslantürk and Saracaloğlu (2010), Demir (2009), Odabaş, Odabaş and Polat (2008), Gömleksiz (2004) and Nell (1988) examined only printed reading attitudes, interests, habits, and reading comprehension skills of university students attending various departments. In addition, UNESCO (2014), CNL (2014), National Endowment for the Arts (2007) and Clark and Foster (2005) focused on current reading habits at an international level by age, sex, type of book read, etc. Thus, the above-mentioned studies and the present study have some aspects in common. The difference of the present study from the above-mentioned studies is that it also addressed the digital reading habits of teacher candidates.

Dökmen (1994), which was similar to the current study, was limited to only a questionnaire study. It was intended for adults and children and aimed to examine reading habits. Though Dökmen (1994) is similar to this study in terms of reading habits, the present study is different in terms of digital reading. 


\subsection{Recommendations}

This study aimed to determine the attitudes of teacher candidates towards reading. Based on the research results, the following recommendations may be put forward:

1. Research measuring the printed and digital reading habits of elementary school and middle school teachers may be conducted.

2. Research measuring the printed and digital reading habits of elementary school and middle school students may be conducted.

3. Research measuring the printed and digital reading habits of academics may be conducted.

4. Reading competency scales may be developed by working on larger samples.

5. New research may be conducted based on demographic data (status of having a library, frequency of reading, frequency of going to library, status of having a computer, frequency of using the Internet, etc.).

\section{References}

Arslantürk, E., \& Saracaloğlu, A. S. (2010). Sınıf Öğretmenlerinin ve Sınıf Öğretmeni Adaylarının Okuma İlgi ve Alışkanlıklarının Karşılaştırılması. Anadolu Üniversitesi Sosyal Bilimler Dergisi, 11(1), 155-176.

Belisle, C. (2004). La lecture Numérique: Réalités, Enjeux et Perspectives. France: Presses de l'ENSSIB, 2004.

Bircan, İ., \& Tekin, M. (1989). Türkiye’de Okuma Alışkanlığının Azalması Sorunu ve Çözüm Yolları. Ankara Üniversitesi Eğitim Bilimleri Dergisi, 22(1), 393-410.

Bozanoğlu, İ. (2004). Akademik Güdülenme Ölçeği; Geliştirmesi, Geçerliği. Ankara Üniversitesi Eğitim Bilimleri Fakültesi Dergisi, 37(2), 83-98. http://dx.doi.org/10.1501/egifak_0000000094

Bozpolat, E. (2010). Öğretmen Adaylarının Okuma Alışkanlığına İlişkin Tutumlarının Değerlendirilmesi (Cumhuriyet Üniversitesi Eğitim Fakültesi Örneği). Zeitschrift für die Welt der Türken Journal of World of Turks, 2(1), 211-228.

Büyüköztürk, Ş. (2007). Sosyal Bilimler için Veri Analizi El Kitabl [Handbook of Data Analysis for Social Sciences], $7^{\text {th }}$ edition, Ankara: Pegem A Yayıncılık.

Clark, C., \& Foster, A. (2005). Children's and Young People's Reading Habits and Preferences: The Who, What, Why, Where and When, National Literacy Trust.

CNL (2014). Les Français et la lecture. France: IPSOS Media CT, 1-58.

Demir, T. (2009). İlköğretim II. Kademe Öğretmen Adaylarının Okuma Alışkanlıkları Üzerine Bir Araştırma (Gazi Üniversitesi Örneği) [A Survey on Reading Habits of Prospective Teachers for Elementary School's Second Grade (Case of Gazi Unıversity)]. Turkish Studies, 4(3), 717-745. http://dx.doi.org/10.7827/TurkishStudies.703

Dökmen, Ü. (1990). Lise ve Üniversite Öğrencilerinin Okuma Becerileri, İlgileri, Okuma Ve Kütüphane Kullanma Alışkanlıkları. Ankara Üniversitesi Ĕ̈itim Bilimleri Fakültesi Dergisi, 23(2), 395-418.

Geçer, A. K. (2012). Öğretmen Adaylarının Ders Çalışma Yaklaşımları ve Bilgi Okuryazarlık Öz-Yeterlikleri Üzerine Bir Çalışma. Egitim Araştırmaları-Eurasian Journal of Educational Research, 49, 151-172.

Gömleksiz, M. N. (2004). Kitap Okuma Alışkanlığına İlişkin Bir Tutum Ölçeğinin Geçerlik ve Güvenirliği. Fırat Üniversitesi Sosyal Bilimler Dergisi, 14(2), 185-195.

Gönen, M., Çelebi-Öncü, E., \& Işıtan, S. (2004). İlköğretim 5, 6. ve 7. Sınıf Öğrencilerinin Okuma Alışkanlıklarının İncelenmesi. Millî Ĕgitim Dergisi, (164), 7-35.

Gorsuch, R. L. (1983). Factor Analysis ( $2^{\text {nd }}$ Edition). Hilldsdale, NJ: Erbaum.

National Endowment for the Arts (2007). To Read or not to Read a Question of National Consequence, 1-99.

Nell, V. (1988). The Psychology of Reading for Pleasure: Needs and Gratifications. Reading Research Quartely, XVII (1), 6-50. http://dx.doi.org/10.2307/747903

Odabaş, H., Odabaş, Y. Z., \& ve Polat, C. (2008). Üniversite Öğrencilerinin Okuma Alışkanlığı: Ankara Üniversitesi Örneği. Bilgi Dünyası, 9(2), 431-465.

Önal, İ. (2010), Tarihsel Değişim Surecinde Yaşam Boyu Öğrenme ve Okuryazarlık: Türkiye Deneyimi. Bilgi Dünyası, 11(1), 101-121.

Saracaloğlu, A. S., Bozkurt, N., \& Serin, O., (2003). Üniversite Öğrencilerinin Okuma İlgileri ve Alışkanlıklarını Etkileyen Faktörler. Eğitim Araştırmaları Dergisi, 4(12), 149-157. 
Semerci, Ç. (2003). Kopya Çekmeye İlişkin Tutum Ölçeği. Fırat Üniversitesi Sosyal Bilimler Dergisi, 13(1), 227-234.

Susar, K. F. (2012). Öğretmen Adaylarının Kitap Okuma Alışkanlığına Yönelik Tutum Ölçeği: Geçerlik ve Güvenirlik Çalışması. Turkish Studies, 7(3), 2353-2366. http://dx.doi.org/10.7827/TurkishStudies.3372

Tanrıverdi, B., Ulusoy, Y., \& Turan, H. (2012). Eleştirel Düşünme Becerilerini Geliştirmesi Açısından Öğretmen Eğitimi Programlarının Değerlendirilmesi. Egitim Araştırmaları Eurasian Journal of Educational Research, 47, 23-40.

Tessier, M. (2010). Rapport sur la Numérisation du Patrimoine Écrit. http://www.lefigaro.fr/assets/pdf/rapport-numerisation.pdf (Retrieved in: 15.08.2014).

Ünalan, Ş. (2006). Türkçe Öğretimi. Ankara: Nobel Yayın Dağıtım.

UNESCO (2014). Reading in the Mobile Era: A Study of Mobile Reading in Developing Countries. 1-87.

Vandendorpe, C. (1999). Du Papyrus à l'hypertexte: Essai sur les Mutations du Texte et de la Lecture. (ISBN 2-89052-979-7), USA: Montréal, Boréal.

Yılmaz, B., Köse, E., \& Korkut, Ş. (2009). Okuma Alışkanlıkları Üzerine Bir Araştırma, Türk Kütüphaneciliği, 23(1), $22-51$.

Yılmaz, B. (1992). Okuma Alışkanlığında Öğretmenin Rolü. Eğitim Dergisi, (1), 10-23.

$21^{s t}$

Century Skills,

Education\&

Competitiveness

(2008).

http://www.p21.org/storage/documents/21st_century_skills_education_and_competitiveness_guide.pdf (Accessed: 15.08.2014).

This work is licensed under a Creative Commons Attribution 3.0 License. 